\title{
Filipino prospective teachers' experiences in teaching in K12 science curriculum: A cross-sectional research
}

\author{
Ace Mark R. Antipolo a,1, Danilo V. Rogayan Jr. a,2," \\ a College of Teacher Education, President Ramon Magsaysay State University, Zambales 2207, Philippines \\ ${ }^{1}$ aceantipolo28@gmail.com; ${ }^{2}$ danrogayan@gmail.com* \\ * Corresponding author
}

\begin{tabular}{ll}
\hline ARTICLE INFO & ABSTRACT \\
\hline Article history & The K12 science curriculum in the Philippines uses spiral progression which is a \\
Received: 4 February 2021 & concept of learning approach where students revisit the same topics throughout their \\
Revised: 8 March 2021 & school career that increases complexity and reinforcement of previous learning. This \\
Accepted: 11 March 2021 & cross-sectional study determined the experiences of Filipino prospective science \\
Published: 29 March 2021 & teachers (PSTs) specializing in biology and physical science in teaching in the K12 \\
& science curriculum with emphasis of their challenges. The respondents of this study \\
Keywords & were 30 PSTs in five teacher education institutions (TEls) in Central Luzon, Philippines. \\
Cross-sectional survey & Results revealed that the PSTs rarely experience teaching challenges in the K12 \\
Experiences in K12 curriculum & science curriculum in terms of content knowledge and pedagogy, learning environment, \\
K12 science curriculum & diversity of learners, curriculum and planning, assessment and reporting, community \\
Science education & linkages and professional engagement, and in personal growth and professional \\
Science prospective teachers & development. No significant differences were noted in the challenges of PSTs when \\
& grouped according to profile variables. A positive significant moderate to high \\
correlations were noted between and among the challenges variables. The study \\
suggests that the administration continuously spearhead in-house seminars and equip \\
prospective teachers with innovative teaching strategies. TEls may also consider \\
curriculum review to align the course syllabi in the teacher education curriculum to the \\
Department of Education curriculum. Schools may further evaluate the policies, \\
standards, and guidelines of the teacher education curriculum to make the science \\
education degree programs relevant.
\end{tabular}

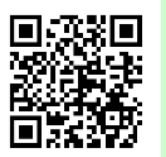

Copyright $\odot$ 2021, Antipolo \& Rogayan This is an open access article under the CC-BY-SA license

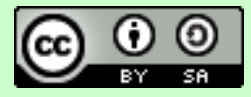

How to cite: Antipolo, A. M. R., \& Rogayan, D. V. Jr. (2021). Filipino prospective teachers' experiences in teaching in K12 science curriculum: A cross-sectional research. JPBI (Jurnal Pendidikan Biologi Indonesia), 7(1), 1-10. doi: https://doi.org/10. 2022219/jpbi.v7i1.15468

\section{INTRODUCTION}

A myriad of concerns continues to hamper the advancement of biology education in the different parts of the globe (Rogayan \& Albino, 2019). The role of universities and colleges is very indispensable in promoting quality biology education and science education in general. Teacher education institutions (TEls) are tasked to develop future teachers proficient in the science content and well-versed in their pedagogy. The new teachers would better understand effective pedagogical approaches if their pre-service training has equipped them with enough experience. They should be equipped with the indispensable skills to be able to effectively contribute to the development of functionally-literate and scientifically-minded citizens (Laguatan \& Abad, 2019). In 
consonance, TEls are challenged to develop globally-competitive, technologically-literate and value-laden would-be science teachers.

Globally, the Philippines lags behind compared to its neighboring countries in terms of education quality, particularly in science education (Rogayan \& Dollete, 2019). According to the 2018 Programme for International Student Assessment (PISA) 2018, the Philippines scored 353 in Mathematics, 357 in Science, and 340 in Reading, all below the average of participating countries (Department of Education [DepEd], 2019). The results were significantly lower than the Organization for Economic Co-operation and Development (OECD) average of 487 points. PISA evaluation is comprised of three basic dimensions, literacy in reading, literacy in mathematics, and literacy in science. In high performing countries like Brunei, Australia and other first-world countries, they apply integrated approach and spiral progression. As Asian nations aspire to join the developed nations, some countries like Malaysia and Singapore implemented the spiral curriculum to establish global competency in the educational system.

In the school year 2012-2013, the K12 curriculum has been implemented. The curricular change in education resulted in congestion in the basic education curriculum. Thus, the government implemented the Republic Act 10533, also known as the K12 program for public and private institutions for the enactment of the spiral curriculum. The current curriculum, which uses spiral progression approach, provided a range of competencies to the learners in a knowledge-based and world of work civilization. It aims for the progress of environmentally, scientifically and technologically educated and prolific community of people who can solve serious problems, accountable users of environment, productive citizens, informed legislators, and effective communicators (K12 Science Curriculum, 2016).

In the Philippines, the spiral curriculum in science presents the concepts and skills in all the branches of science including biology, chemistry, physics, and earth science, with increasing complexity levels from one grade level to another in spiral progression, thus the concrete way to a better understanding of core concepts. The incorporation of science across subjects and other disciplines will lead to meaningful learning in the concepts and their purpose in real-life situations. However, prospective teachers, especially those majoring in a specific discipline like biological sciences and physical sciences, face difficulties in teaching in a spiral curriculum since the science content is integrative. Mizzi (2013) supported this claim, which stated that the mismatch to the area of specialization offers considerable challenges, especially in the lesson planning; therefore, the teaching-learning process will later be affected due to lack of information. Teacher's lack of expertise in the subject will affect their confidence manifested in different ways including lesson planning, answering the questions of students, proper set up of laboratory activities, involving and applying the concepts and principles to everyday life situations, generating the students' interest and excitement for the science area.

Local studies regarding K12 science curriculum have been extensively done. These studies focused on the teachers' and students' perception on the implementation of the curriculum (Acosta \& Acosta, 2017; Montebon, 2014), the assessment of the curriculum (Cabansag, 2014; Rivera, 2017; Sañosa, 2013), spiral progression approach in teaching science (De Ramos-Samala, 2018; Dunton, 2015; Gonzales, 2019; Maing et al., 2019; Mangali et al., 2019; Orbe et al., 2018; Resurreccion, \& Adanza, 2015), preparedness and self-efficacy of teachers in teaching in K12 science curriculum (Sakib \& Obra, 2019; Walag et al., 2020), and the philosophical foundation of science education in the country (Miranda, 2014). Likewise, previous studies on science prospective teachers focused on their experiences in teaching beyond their specialization (Montebon, 2015), reasons for choosing general science as majorship (Manalansan et al., 2020), self-efficacy of prospective teachers (Aure \& Jugar, 2017), science laboratory interest and preferences (Antonio, 2018), preservice science teacher preparation and education (Handa, 2012; Handa \& Tippins, 2013), and technology integration in teaching science (Mercado et al., 2019).

The biology and physical science prospective teachers' challenges in teaching in the K12 science curriculum need to be properly addressed to increase their teaching proficiency. With the current curriculum's spiral progression approach, the mastery of knowledge and skills after each level of the students will be ensured. With effective prospective teachers, quality of teachers who will teach in the field will be attained. The quality of teachers in the Philippines is also anchored on the Philippine Professional Standards for Teachers (PPST). PPST is a standardized measure to assess teacher performance, identify their needs, and provide support for professional development (Department of Education, 2017).

Hence, the researchers conducted this study to explore the experiences of the prospective science teachers (PSTs) in teaching in K12 science curriculum. This paper is the first attempt to document the challenges of the PSTs in the spiral progression approach in the Philippine K12 curriculum based on the framework of the PPST which can be an important literature to further understand prospective teachers' challenges in other specializations. 


\section{METHOD}

The study utilized a descriptive cross-sectional research. This research surveyed the challenges experienced by biology and physical science preservice science teachers in teaching in the K12 science curriculum. A descriptive survey was used to distinguish a condition, people, action, or phenomenon. According to Atmowardoyo (2018), descriptive research is used to describe the existing phenomena as accurately as possible and these phenomena are already available. The most common descriptive research method is the survey, which includes questionnaires, personal interviews, phone surveys, and normative surveys.

The respondents of this study are the preservice science teachers in five teacher education institutions in Central Luzon, Philippines (Table 1). The respondents were chosen through stratified random sampling. Stratified random sampling is a method of sampling that involves the division of a population into smaller groups known as strata. In stratified random sampling, the strata were formed based on members' shared attributes or characteristics. These subsets of the strata were then pooled to form a random sample.

\begin{tabular}{llrr}
\multicolumn{5}{c}{ Table 1. Distribution of respondents } \\
\hline School & Classification & Frequency & Percentage (\%) \\
\hline TEI A & SUC & 7 & 23.33 \\
TEI B & SUC & 9 & 30.00 \\
TEI C & Private HEI & 8 & 26.67 \\
TEI D & Private HEI & 2 & 6.67 \\
TEI E & LUC & 4 & 13.33 \\
\hline Total & & 30 & 100.0 \\
\hline
\end{tabular}

where TEl: Teacher Education Institution, SUC: State University and College, HEl: Higher Education Institution, and LUC: Local University and College. As shown, the study involved two teacher education institutions from state universities and colleges (SUCs), two private higher education institution (HEls), and one local college and university (LUC).

Table 2 shows the profile of the science preservice teachers.

Table 2. Profile of the science preservice teachers

\begin{tabular}{llll}
\hline & Profile & Frequency & Percentage (\%) \\
\hline School & Private & 10 & 33.33 \\
& Public & 20 & 66.67 \\
& Total & 30 & 100.0 \\
\hline Age & $19-20$ & 12 & 40.00 \\
& $21-22$ & 12 & 40.00 \\
& $23-24$ & 2 & 6.67 \\
& $25-$ above & 4 & 13.33 \\
& Total & 100.0 \\
\hline Sex & Male & 30 & 40.00 \\
& Female & 12 & 60.00 \\
& Total & 18 & 100.0 \\
\hline Civil status & Single & 30 & 90.00 \\
& Married & 27 & 10.00 \\
& Total & 3 & 100.0 \\
\hline Specialization & BSEd Biological Science & 30 & 76.67 \\
& BSEd Physical Science & 23 & 23.33 \\
& Total & 7 & 100.0 \\
\hline Grade level handled & Grade 7 & 30 & 33.33 \\
& Grade 8 & 10 & 43.33 \\
& Grade 9 & 13 & 43.33 \\
& Grade 10 & 13 & 43.33 \\
& Grade 11 & 13 & 13.33 \\
& Grade 12 & 4 & 26.67 \\
\hline
\end{tabular}

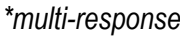

As shown in the Table 2, most of the respondents enrolled in public education institutions like state universities and colleges (SUCs) and local universities and colleges with 20 or $66.67 \%$ while $10(33.33 \%)$ enrolled in private higher education institutions (HEls). Out of 30 respondents, $12(40.00 \%)$ is in the age of 1920 and $21-22$, two or $6.67 \%$ are aged $23-24$ and 4 or $13.33 \%$ are 25 -above. This shows that a typical science preservice teacher is at their early 20 s. 
Out of 30 science preservice teachers, 18 or $60.00 \%$ are female and 12 or $40.00 \%$ are male. The result shows that there is a greater number of female respondents. This confirms with the trend that teaching is a female dominated profession. A majority (27 or $90.00 \%$ ) are single and only few (3 or $10.00 \%)$ are married. The result shows that the greater number of respondents are single. Majority $(23$ or $76.67 \%)$ are biological science majors and 7 or $23.33 \%$ are physical science major. This implies that majority are takers of biological science majorship. A total of $13(43.33 \%)$ handled Grade 8, 9 and 10, $10(33.33 \%)$ handled Grade 7, 8 $(26.67 \%)$ handled Grade 12 and $4(13.33 \%)$ handled Grade 11 . The result shows that the greater number of respondents handled Grade 8, 9 and 10.

The Challenges in Teaching K12 Science Curriculum questionnaire (CTK12SCQ) developed by the researchrs served as the main instrument in gathering the data. The survey tool is a researcher-made questionaire based from the Philippine Professional Standards for Teachers (Department of Education, 2017). The first part consists of the demographic profile of the participants. The profile of the preservice science teachers include age, sex, civil status, specialization and grade level handled. The second part assessed the challenges experienced by the preservice science teachers during their practice teaching which consists of 37 items, which, include content knowledge and pedagogy (7 items); learning environment (6 items); diversity of learners (5 items); curriculum and planning (5 items); assessment and reporting (5 items); community linkages and professional engagement (4 items), and personal growth and professional development (5 items).

The survey questionnaire was subjected to construct and content validity. Three experts were tapped to check the consistency of the items in each variable. A total of 10 preservice teachers who were not part of the study were asked to answer the survey questionnaire for pilot testing. The responses were processed and was subjected to a reliability test. The Cronbach alpha value of the questionaire was 0.80 to 0.99 which indicated high-reliability index that allowed the questionnaire to be used in the study.

After developing the research questionnaire and validation of four experts, the researchers asked permission from school administrators of the four higher education institutions to conduct the survey. All the PSTs were involved in the data gathering and the informed consent was secured before they answered the questionnaires. The research survey was floated to 30 prospective teachers. Retrieval of the survey tools was done on the same day.

The computer software SPSS version 20 and MS Excel 2013 were used for the processing of data. The statistical tools which used in the analysis and interpretation of data and hypotheses were fequency count, percent, weighted mean, analysis of variance (ANOVA) and Pearson-r correlation.

The researchers followed strict ethical protocols in the conduct of this study. The respondents' names were not mentioned in any part of this research. The respondents were not emotionally or physically harmed in the duration of the survey. Coding scheme was used in identifying the subjects of the study. Proper in-text and reference citation were followed in the preparation of the research article. Prior approval of the authorities was secured before conducting the survey to the intended respondents.

\section{RESULTS AND DISCUSSION}

Table 3 shows the challenges experienced by science prospective teachers (PSTs) in seven domains. As shown in the table, the respondents rarely encounter challenges in teaching in $\mathrm{K} 12$ science curriculum using spiral progression approach based on the overall mean of $2.19(S D=0.59)$.

Table 3. Challenges experienced by prospective teachers

\begin{tabular}{rlrrr}
\hline Indicators & m & sd & Description \\
\hline 1. & Content knowledge and pedagogy & 2.36 & 0.54 & Rarely \\
2. & Learning environment & 2.11 & 0.50 & Rarely \\
3. & Diversity of learners & 2.09 & 0.61 & Rarely \\
4. & Curriculum and planning & 2.27 & 0.60 & Rarely \\
5. & Assessment and reporting & 2.06 & 0.65 & Rarely \\
6. & Community linkages and professional development & 2.44 & 0.65 & Rarely \\
7. & Personal growth and professional development & 2.01 & 0.60 & Rarely \\
\hline \multicolumn{2}{r}{ Total } & $\mathbf{2 . 1 9}$ & $\mathbf{0 . 5 9}$ & Rarely \\
\hline
\end{tabular}

The highest means were obtained in community linkages and professional development $(M=2.44, S D=$ $0.65)$, content knowledge and pedagogy $(M=2.36, S D=0.54)$ and curriculum and planning $(M=2.27, S D=$ $0.60)$. This implies that the PSTs rarely experience difficulties in linking with parents and community people, mastering their content matter and instructional approaches, and designing their learning plans. 
The lowest means were obtained in the domains of learning environment $(M=2.11, S D=0.50)$, diversity of learners $(M=2.09, S D=0.61)$, assessment and reporting $(M=2.06, S D=0.65)$, and personal growth and professional development $(M=2.01, S D=0.60)$. This suggests that the respondents likewise do not encounter challenges in designing their learning spaces, dealing with a multitude of learners, evaluating the learners through varied tools and techniques, and furthering their skills and capabilities as prospective science teachers.

In content knowledge and pedagogy, the respondents seldom face difficulties in the use of English in teaching science, positive use of ICT in science classes and in developing critical and creative thinking among students. The teachers' subject content knowledge is a prerequisite to effective teaching practice. Even if teachers are aware of the dynamic forces and intricacy of living systems in biology and geography, they might not deliver its relevance to the students effectively (Rosenkranzer et al., 2017).

The respondents also rarely face problems in the learning environment. They can employ positive and non-violent discipline in dealing with learner action. Also, they understand well the learning environments that uphold equality, reverence, and care to inspire learning. If teacher educators are prepared to support the education of students, it is imperative to know the interest of the students. Students have different preferences when acquiring knowledge in education (Plackle et. al., 2014).

As to diversity of learners, PSTs barely experience challenges in utilizing science teaching strategies that are responsive to students' various backgrounds. They were also well-versed in selecting inclusive teaching strategies that cover marginalized groups like the indigenous groups and learners with disabilities. The result is supported by the study of Beutel and Tangen (2018) that emphasized that the consensus of curriculum offered in teacher education has a significant impact in developing the competencies of future teachers, the greatest challenge is how to give them enough experiences to teach in the future effectively.

In terms of curriculum and planning, the respondents rarely struggle in identifying learning objectives that are aligned with science learning competencies and using a variety of teaching and learning resources. Hsu (2017) stated that many subjects in teacher education programs for prospective teachers, including content and methodology subjects, draw on conventional and lecture-delivered approaches. In contrary, the results show that the PSTs rarely experience difficulty in curriculum and planning that indicates a good curriculum offered in the teacher education.

The prospective teachers do not often experience challenges in understanding the role of assessment data as feedback mechanisms to improve practice, develop programs and inform policies. Likewise, the PSTs are good at monitoring and evaluating the students' progress and achievement using assessment data. Assessment is critical in the teaching-learning process. Through proper assessment, teachers will be able to classify students accordingly (Tosuncuoglu, 2018). The result is also supported by the study of Khosravi and Cooper (2018), which emphasized that the application of assessment for different offerings of a curriculum (within or across terms), providing significant response about student achievements, and the track of student development over time is all challenging job.

In terms of community linkages and professional development, the respondents rarely encounter challenges. PSTs infrequently experience low participation of school community and parents in sciencerelated activities. It is also evident that the prospective teachers have awareness of the rules and regulations applicable to the profession where they are in. Parents and teachers' good relationships can develop the teachers' perception and perspective of students' specific character such as family background and learning needs (Thijs \& Eilbracht, 2012). The results show that science preservice teachers have high engagements to parents which led to high engagement of the community in science learning. This conforms to the study of Mautone et al (2015), which emphasized that understanding facilitates greater individualization of support that educators give to learners and families will also reduce the negative prejudices on the part of educators toward learners and families. The future teachers were aware of the crucial importance of parental involvement in students' academic development and achievements. The student teaching practice contributed significantly to their current level of parental involvement training and an awareness of varied family patterns (Sukhbaatar, 2018).

Likewise, the respondents rarely encounter challenges in terms of personal growth and professional development. They do not experience difficulties in applying practices that sustain the dignity of science teaching as a vocation. They also exhibit well learner-centered teaching philosophy. Akhmetova et al (2016) emphasized that the would-be teachers must be ready for ethical and spiritual growth of high-school students in the context of holistic manifestation of all facets of personality. Additionally, TEls must be aggressive in 
implementing programs and activities that will develop prospective teachers' personal growth and professional development (Reusia et al., 2020).

Based on the independent sample t-test, there is no statistically significant difference between the challenges experienced of private/public science preservice teachers. Although not significant, science preservice teachers from public have greater challenges than the private school counterparts in terms of content knowledge and pedagogy and learning environment. Though not significant, science preservice teachers from private have greater challenges than their public-school counterparts in terms of diversity of learners.

There is no significant difference between private and public school in terms of challenges in mastery of subject matter content in contrary to the findings of the study of Turkcapar (2015) which highlighted that there is a significant difference in school variable favored to public schools in terms of orientation and mastery. Likewise, there were no statistically significant differences at the 0.05 level of significance in the challenges mean scores of the respondents by age. There is no sufficient evidence to show statistically significant differences in the respondents' challenges by age which is probably due to the small sample size taken or might be due to the large error of measurement. Moreover, there were no significant differences between the means of the challenges of science preservice teachers by sex. Although not significant, female respondents faced greater challenges compared to the male respondents in all domains.

There were also no significant differences between the challenges of science preservice teachers by civil status. Regardless of being single or married, prospective teachers experience the same level of challenges. This confirms the findings of Elom and Egba (2015) that marital stress will not affect the job satisfaction of women teachers. it was concluded that marital stress could not predict job satisfaction among married women teacher. This implies that a teacher's civil status does not contribute to teachers' performances that might later affect their capability in teaching. This also indicates that the civil status cannot be considered a factor that affects a teacher's effectiveness whether he or she is married or not.

Lastly, there existed no significant differences between the means of science preservice teachers' challenges according to specialization and grade level handled. This implies that whether the PSTs specialize in biological science or physical science, they have experienced the same level of challenges. In relation, Mizzi (2013) concluded that there are substantial differences when teaching within and beyond areas of specialization. Teachers are more confident when they teach in the area of their expertise.

Table 4 shows the relationship among the variables of the challenges of science preservice teachers in teaching in K12 science curriculum. As gleaned from the Table 4, inter-correlations among all dimensions of challenges in teaching spiral curriculum in science are positive and significantly correlated. There is a low to very high correlations between and among the dimensions of challenges experienced by the prospective teachers. This suggests that as one dimension of challenge increases, another corresponding dimension will likely increase.

Table 4. Correlation between respondents' challenges of science preservice teachers in teaching in $\mathrm{K} 12$ science curriculum

\begin{tabular}{lllllll}
\hline \multicolumn{1}{c}{ Variables } & $\mathbf{1}$ & $\mathbf{2}$ & $\mathbf{3}$ & $\mathbf{4}$ & $\mathbf{5}$ & $\mathbf{6}$ \\
\hline 1. Content knowledge and & - & & & & & \\
pedagogy & $0.717^{* *}$ & - & & & & \\
2. Learning environment & $0.629^{* *}$ & $0.779^{* *}$ & - & & & \\
3. Diversity of learners & $0.834^{* *}$ & $0.756^{* *}$ & $0.695^{* *}$ & - & & \\
4. Curriculum and planning & $0.779^{* *}$ & $0.633^{* *}$ & $0.684^{* *}$ & $0.871^{* *}$ & - & \\
5. Assessment and reporting & $0.745^{* *}$ & $0.587^{* *}$ & $0.590^{* *}$ & $0.745^{* *}$ & $0.708^{* *}$ & - \\
6. Community linkages and & professional engagement & & & & & \\
7. Personal growth and & $0.473^{* *}$ & $0.531^{* *}$ & $0.622^{* *}$ & $0.611^{* *}$ & $0.709^{* *}$ & $0.690^{* *}$ \\
\hline
\end{tabular}

${ }^{*}$ Correlation is significant at the 0.01 level (2-tailed)

${ }^{*}$ Correlation is significant at the 0.05 level (2-tailed)

Equipping the would-be science teachers with the necessary skills, attitudes and values with the support of their family, mentors and school administration, would minimize the challenges they encounter in their preservice education. Science prospective teachers should be equipped with the necessary knowledge and skills in pedagogy, assessment, teaching material development, classroom-based action research and other trends and issues in STEM education (Rogayan, 2019). Teacher educators should lead in the enhancement 
of the prospective teachers' TPACK as they embrace the challenges of Education 4.0 and the VUCAD2 (volatile, uncertain, complex, ambiguous, diverse, and disruptive) world.

\section{CONCLUSION}

The study determined the experiences of prospective science teachers (PSTs) in teaching under K12 science curriculum which uses spiral progression approach. The PSTs rarely encounter challenges in teaching in the spiral curriculum in terms of the seven dimensions which include content knowledge and pedagogy, learning environment; diversity of learners; curriculum and planning; assessment and reporting; community linkages and professional engagement, and personal growth and professional development. There is no significant difference in the challenges of science prospective teachers when grouped according to profile variables. There are low to very high positive significant relationship between and among the seven dimensions of challenges experienced by preservice teachers.

The administration may allocate adequate funding for the provision of additional instructional facilities and equipment. The college administration may in-house spearhead seminars and trainings inside the university to equip prospective science teachers with innovative teaching strategies and to develop content knowledge and another pedagogical dimensions. An orientation on spiral progression approach of the K12 science curriculum may be conducted to make science preservice teachers be aware of the curriculum policies, standards and guidelines. The teacher educators teaching special education courses may revisit their course syllabi to address the need for science integrative teaching to align this in K12 curriculum. Science teachers in the college may also do mentoring session to address the least mastered topics of preservice science teachers before their teaching internship. An assessment of the PSTs' technological pedagogical and content knowledge (TPACK) may be considered a baseline for pedagogical intervention.

Since the study was conducted during the pre-pandemic period, further study may also look into the challenges of the prospective science teachers in the VUCAD2 world which was aggravated with the COVID-19 pandemic. The PPST framework may also be utilized as lens in understanding the challenges of the PSTs during the emergency remote education brought about by the COVID-19 pandemic. The experiences of the prospective teachers in navigating the new normal science education may also be explored where flexible learning modality during educational disruption is used. Facilitating biology and other science laboratory experiments during COVID-19 educational disruption may also be explored. Lastly, conducting student assessment during the COVID-19 learning era may be probed in future studies.

\section{ACKNOWLEDGEMENT}

The authors would like to acknowledge the school administrators of the higher education institutions for the approval to conduct the study, to the prospective teachers for the participation, to the College of Teacher Education of the President Ramon Magsaysay State University - San Marcelino Campus for the support to this research work, to the critics, editors and anonymous reviewers for the valuable insights which improved this research article.

\section{REFERENCES}

Acosta, I. C., \& Acosta, A. S. (2017). A mixed methods study on teachers' perceptions of readiness of higher education institutions to the implementation of the K-12 Curriculum. Universal Journal of Educational Research, 5(7), 1215-1232. https://doi.org/10.13189/ujer.2017.050714

Akhmetova, A. I., Shirinbaeva, G., \& Ussein, G. A. (2016). Structural components of psychological and pedagogical readiness of the future teachers to the spiritual and moral development. In International Scientific and Practical Conference World Science (Vol. 3, No. 9, pp. 10-12). ROST. https://cyber leninka.ru/article/n/structural

Antonio, V. V. (2018). Science laboratory interest and preferences of teacher education students: Implications to science teaching. Asia Pacific Journal of Multidisciplinary Research, 6(3), 57-67. http://www.apjmr. com/wp-content/uploads/2018/07/APJMR-2018.6.3.08a.pdf

Atmowardoyo, H. (2018). Research methods in TEFL studies: Descriptive research, case study, error analysis, and R \& D. Journal of Language Teaching and Research, 9(1), 197-204. https://doi.org/10. 17507/j|tr.0901.25 
Aure, M. R. K. L., \& Jugar, R. R. (2017). A cross-sectional study on the self-efficacy of pre-service science and mathematics teachers in a Philippine State University. Annals of Tropical Research, 39(1), 135146. https://doi.org/10.32945/atr3919.2017

Beutel, D. A., \& Tangen, D. (2018). The impact of intercultural experiences on preservice teachers' preparedness to engage with diverse learners. Australian Journal of Teacher Education, 43(3), 168179. http://dx.doi.org/10.14221/ajte.2018v43n3.11

Cabansag, M. G. S. (2014). Impact statements on the K-12 science program in the enhanced basic education curriculum in provincial schools. Researchers World, 5(2), 29-39. https://www.semanticscholar.org/ paper/impact

De Ramos-Samala, H. (2018). Spiral progression approach in teaching Science: A case study. KnE Social Sciences, 555-567. https://doi.org/10.18502/kss.v3i6.2404

Department of Education. (2017). National adoption and implementation of the Philippine professional standards for teachers (Dep Ed Order 42 s. 2017). https:/www.deped.gov.ph/wp-content/uploads/ 2017/08/DO_s2017_042-1.pdf

Department of Education. (2019). PISA 2018 national report of the Philippines. Department of Education. https://www.deped.gov.ph/wp-content/uploads/2019/12/PISA-2018-Philippine-National-Report.pdf

Dunton, J. B. (2019). Spiral progression approach in teaching science and the performance of learners in District I, Capiz. In Journal of Physics: Conference Series (Vol. 1254, No. 1, p. 012045). IOP Publishing. https://doi.org/10.1088/1742-6596/1254/1/012045

Elom, S. O., \& Egba, N. A. (2015). Marital stress and extraversion personality as predicators of job satisfaction among married women teachers in Enugu, Nigeria. Journal of Education and Practice, 6(33), 61-66. https://files.eric.ed.gov/fulltext/EJ1083492.pdf

Gonzales, N. J. (2019). Narrative experience of seasoned teachers in teaching science using spiral progression curriculum. IOER International Multidisciplinary Research Journal, 1(2), 59-68. https:// papers.ssrn.com/sol3/papers.cfm?abstract_id $=3418396$

Handa, V. C., \& Tippins, D. J. (2012). Cultural memory banking in preservice science teacher education. Research in Science Education, 42(6), 1201-1217. https://doi.org/10.1007/s11165-0119241-6

Handa, V. C., \& Tippins, D. J. (2013). Tensions in the third space: Locating relevancy in preservice science teacher preparation. International Journal of Science and Mathematics Education, 11(1), 237-265. https://doi.org/10.1007/s10763-012-9364-x

Hsu, P.-L. (2016). Science teaching experiences in informal settings: one way to enrich the preparation program for preservice science teachers. Universal Journal of Educational Research, 4(5), 1214-1222. https://doi.org/10.13189/ujer.2016.040535

K12 Science Curriculum Guide (2016). Department of Education. http://www.deped.gov.ph/wpcon tent/uploads/2019/01/Science-CG_with-taggedsci-equipment_revised.pdf

Khosravi, H., \& Cooper, K. (2018). Topic dependency models: graph-based visual analytics for communicating assessment data. Journal of Learning Analytics, 5(3), 136-153. https://doi.org/10. 18608/jla.2018.53.9

Laguatan, R. P., \& Abad, B. D. (2019). Science teacher's qualities: The basis for a faculty sustainability program. International Journal of Innovation, Creativity and Change, 8(7), 232-249. https://eric.ed.gov/ ?id=ED606758

Maing, E. M., Mangadang, A. T., Salic-Hairulla, M. A., Canalita, E. E., Sequente, F. R., \& Yuenyong, C. (2019, October). Assessment of science teacher competence in teaching secondary science with spiral progression approach. In Journal of Physics: Conference Series (Vol. 1340, No. 1, p. 012059). IOP Publishing. https://doi.org/10.1088/1742-6596/1340/1/012059

Manalansan, E. B. R., Fogata, M. A., \& Rogayan, D. V. Jr. (2020). Exploring prospective teachers' reasons for choosing general science as a specialization. Journal of Science Learning, 3(3), 149-155. https://doi.org/10.17509/jsl.v3i3.23493

Mangali, G. R., Tongco, C., Aguinaldo, K. P., \& Calvadores, C. J. (2019). Stories of students toward spiral progression approach in science: A phenomenological study. International Journal of Multidisciplinary Research and Publications, 2(2), 27-48. http://ijmrap.com/wp-content/uploads/2019/07/JJMRAPV2N2P11Y19.pdf 
Mautone, J. A., Marcelle, E., Tresco, K. E., \& Power, T. J. (2015). Assessing the quality of parent-teacher relationships for students with ADHD. Psychology in the Schools, 52(2), 196-207. https://doi.org/10. 1002/pits.21817

Mercado, J. N. L., Panganiban, V. J. M., \& Ramos, T. M. I. (2019). Technology integration in teaching science using TPACK among pre-service science teachers of St. Bridget College, Batangas City, Philippines. IOER International Multidisciplinary Research Journal, 1(1), 67-75. https://ssrn.com/abstract=3379278

Miranda, J. R. L. (2014). An analysis of philosophical foundation of science education in the Philippines. Journal of Science \& Technology, 1(1), 1. https://ssctjst.org/index.php/jst/article/view/41

Mizzi, D. (2013). The challenges faced by science teachers when teaching outside their specific science specialism. Acta Didactica Napocensia, 6(4), 1-6. https://eric.ed.gov/?id=EJ1053677

Montebon, D. T. (2014). K12 science program in the Philippines: Student perception on its implementation. International Journal of Education and Research, 2(12), 153-164. https://ijern.com/ journal/2014/December-2014/15.pdf

Montebon, D. R. T. (2015). Science pre-service teachers experience on teaching beyond subject expertise. Journal of Science and Mathematics Education in Southeast Asia, 38(2), 126-139. https:/l eric.ed.gov/?id=EJ1177143

Orbe, J. R., Espinosa, A. A., \& Datukan, J. T. (2018). Teaching chemistry in a spiral progression approach: Lessons from science teachers in the Philippines. Australian Journal of Teacher Education, 43(4), 1730. https://doi.org/10.14221/ajte.2018v43n4.2

Plackle, I., Könings, K. D., Jacquet, W., Struyven, K., Libotton, A., van Merriënboer, J. J., \& Engels, N. (2014). Students' preferred characteristics of learning environments in vocational secondary education. International Journal for Research in Vocational Education and Training (IJRVET), 1(2), 107-124. https://doi.org/10.13152/ijvet.1.2.2

Resurreccion, J. A., \& Adanza, J. (2015, March). Spiral progression approach in teaching science in selected private and public schools in Cavite. In Proceedings of the DLSU Research Congress (Vol. 3, pp. 112). http://uruae.org/siteadmin/upload/UH0516148.pdf

Reusia, D. H. R., Danilo Jr, V. R., \& Andres, K. P. (2020). Science education graduates of a state university from 2008-2018: A tracer study. The Normal Lights, 14(1), 56-79. https://po.pnuresearchportal.org/ ejournal/index.php/normallights/article/view/1496

Rivera, J. G. (2017). Articulating the foundations of Philippine $K$ to 12 curriculum: Learnercenteredness. AsTEN Journal of Teacher Education, 2(1), 59-70. https://po.pnuresearchportal.org/ ejournal/index.php/asten/article/view/554

Rogayan, D. V. Jr., \& Dollete, L. F. (2019). Development and validation of physical science workbook for senior high school. Science Education International, 30(4), 284-290. https://doi.org/10.33828/sei.v30. i4.5

Rogayan, D. V. Jr. \& Albino, M.M. (2019). Filipino students' common misconceptions in biology: Input for remedial teachıng. Online Science Education Journal, 4(2), 90-103. https://dergipark.org.tr/en/pub/ ofed/issue/50430/567349

Rogayan, D. V., Jr. (2019). Retrospective evaluation of the science education program in a Philippine state university. International Journal of Innovation, Creativity \& Change, 8(7), 352- 369. https://eric.ed.gov/? id=ED603046

Rosenkranzer, F., Hörsch, C., Schuler, S., \& Riess, W. (2017). Student teachers' pedagogical content knowledge for teaching systems thinking: effects of different interventions. International Journal of Science Education, 39(14), 1932-1951. https://doi.org/10.1080/09500693.2017.1362603

Sakib, E. J., \& Obra Jr, M. R. (2019). Teachers' preparedness in teaching K to 12 secondary science curriculum. Asia Pacific Journal of Multidisciplinary Research, 7(2), 123-132. http://www.apjmr.com/wpcontent/uploads/2019/06/APJMR-2019.7.2.2.14.pdf

Sañosa, M. E. (2013). Implementation of $K$ to 12 curriculum program among grade 7 science teachers in Eastern Visayas. Journal of Society and Technology, 3(1), 37-44. http://www.jst-online.org/index.php/ JST/article/view/10

Sukhbaatar, B. (2018). Preservice teachers' views on working with diverse families in Mongolia. School Community Journal, 28(1), 295-318. https://eric.ed.gov/?id=EJ1184926

Thijs, J., \& Eilbracht, L. (2012). Teachers' perceptions of parent-teacher alliance and student-teacher relational conflict: Examining the role of ethnic differences and "disruptive" behavior. Psychology in the Schools, 49(8), 794-808. https://doi.org/10.1002/pits.21635 
Tosuncuoglu, I. (2018). Importance of Assessment in ELT. Journal of Education and Training Studies, 6(9), 163-167. https://doi.org/10.11114/jets.v6i9.3443

Turkçapar, U. (2015). Analyzing state and private school students achievement goal orientation levels in terms of some variables. Educational Research and Reviews, 10(20), 2695-2701. https://doi.org/10. 5897/err2015.2458

Walag, A. M. P., Fajardo, M. T. M., Guimary, F. M., \& Bacarrisas, P. G. (2020). Science teachers' self-efficacy in teaching different $\mathrm{K}$ to 12 science subjects: The case of Cagayan De Oro City, Philippines. Science International (Lahore), 32(5), 587-592. https://www.researchgate.net/publication/344892479 